\title{
Initiative for Policy Dialogue
}

Is Domestic Debt the Answer

To Debt Crises?

Ugo Panizza

Task Force on Debt Restructuring and

Sovereign Bankruptcy

The opinions expressed in these papers represent those of the author(s) and not The Initiative for Policy Dialogue. These papers are unpublished. Do not cite them without explicit permission from the author(s). 


\title{
IS DOMESTIC DEBT THE ANSWER TO DEBT CRISES?
}

\author{
Ugo Panizza $^{1}$
}

December 2007

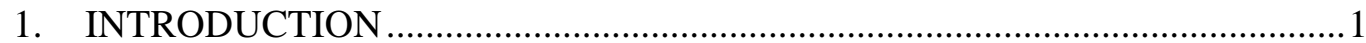

2. THE NATURE AND SIZE OF THE GROWING RESORT TO DOMESTIC

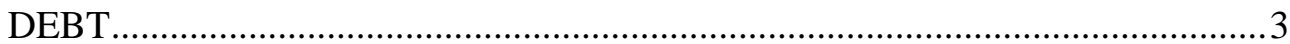

2.1. New Environment, Old Dichotomies......................................................4

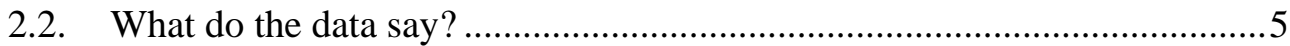

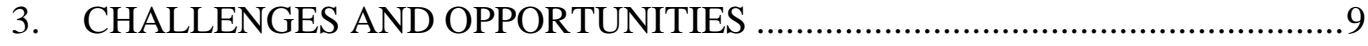

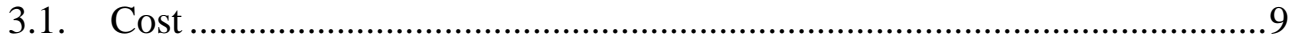

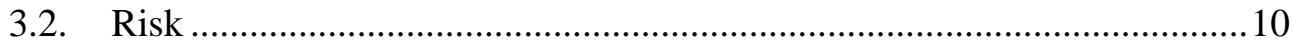

3.3. Public Debt and the Domestic Financial Sector ........................................13

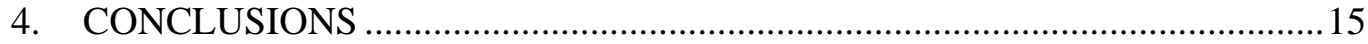

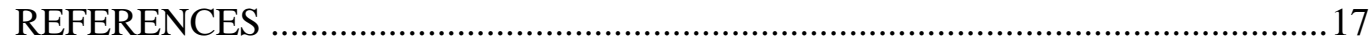

\footnotetext{
${ }^{1}$ Debt and Finance Analysis Unit, Division of Globalization and Development Strategies, UNCTAD. Palais des Nations, 1211 Geneva (CH). Email: Ugo.Panizza@unctad.org. I would like to thank Barry Herman, Shari Spiegel, and Monica Yañez for useful comments. The usual caveats apply. The views expressed in this paper are my own and should not be attributed to UNCTAD.
} 


\section{INTRODUCTION}

Analysis of public debt in developing countries has traditionally focused on external debt. However, in recent years several countries have looked increasingly to domestic sources when expanding their net borrowing or adopted aggressive policies aimed at retiring public external debt and substituting it with domestically issued debt. Some countries are even building up domestic fiscal liabilities with the objective of sterilizing enlarged aid inflows. This chapter asks what possible challenges and opportunities might be arising from these new developments in sovereign debt management.

Past research has focused on external debt for two reasons. First, while external borrowing can increase a country's access to resources, domestic borrowing only transfers resources within the country, albeit from private to public hands. Second, since central banks in developing countries cannot print the hard currency necessary to repay external debt, external borrowing is usually associated with vulnerabilities that may lead to debt crises.

However, the recent emphasis on domestic borrowing may just lead countries to trade one type of vulnerability for another. For instance, countries that are switching from external to domestic debt could be trading a currency mismatch for a maturity mismatch; i.e., they need to be able to pay off or roll over maturing and short-term obligations. Alternatively, the switch to domestic borrowing could lead to pressure on institutional investors and banks to absorb "too much" government debt and this may have a negative effect on financial stability and crowd out private issuers. Finally, there are political economy reasons that may make domestic debt more difficult to restructure. In fact, a few highly indebted countries which were able to use debt relief initiatives to address their external debt problems are still burdened with high levels of domestic debt. It is also important to correctly evaluate the cost of borrowing in different currencies. In an environment in which several emerging currencies are expected to appreciate vis-à-vis the US dollar, the ex post interest rate in domestic currency may end up being higher than that in dollars.

Even with these caveats, I think that the recent trends will have a positive effect on reducing the probability of a debt crisis, and that policymakers' interest in safer forms of finance is a very welcome development. ${ }^{2}$ There are, however, several analytical issues that need to be addressed, both to help policymakers think through the pros and cons of additional domestic borrowing and to effectively monitor that borrowing. Thus, Section 2 of this chapter discusses different definitions of external and domestic

\footnotetext{
${ }^{2}$ Throughout this chapter, "safer" debt will indicate debt that is safer from the borrower's (and not the lender) point of view. For instance, domestic currency debt is safer than foreign currency debt because its burden is less likely to increase after a depreciation of the real exchange rate.
} 
debt and describes broad trends in the composition of public debt in developing countries. Then, Section 3 discusses trade-offs in debt management and Section 4 concludes. 


\section{THE NATURE AND SIZE OF THE GROWING RESORT TO DOMESTIC DEBT}

So far, I referred to external and domestic debt without providing an accurate definition of the terms. There are three possible definitions of external (and thus, domestic) debt. The first focuses on the currency in which the debt is issued (with external debt defined as foreign currency debt). The second focuses on the residence of the creditor (external debt is debt owed to non-residents). The third focuses on the place of issuance and the legislation that regulates the debt contract (external debt is debt issued in foreign countries and under the jurisdiction of a foreign court).

The first definition does not seem appropriate because several countries issue foreign currency denominated debt in the domestic markets and have recently started to issue domestic currency denominated debt in international markets. Moreover, a definition based on the currency composition of public debt would be hard to implement given the limited information on the currency composition of domestic debt. This does not mean that countries should not report information on the currency composition of their external debt. However, currency composition should not be confused with the definition of external debt.

The second definition is the one which is officially adopted by the main compilers of statistical information on public debt (see the External Debt Statistics: Guide for Compilers and Users jointly published by the Bank for International Settlements, Eurostat, International Monetary Fund (IMF), Organization for Economic Cooperation and Development, Paris Club, United Nations Conference on Trade and Development (UNCTAD), and the World Bank). This definition makes sense from a theoretical point of view because it correctly captures the transfers of resources between residents and non-residents; it allows one to capture the amount of international risk sharing and the income effects of variations in the stock of debt, and to evaluate the political cost of a default on public debt. However, this definition is almost impossible to apply in the current environment where most external debt due to private creditors takes the form of bonds (things were easier when most external debt owed to private creditors was channeled through syndicated bank loans). Of course, countries could try to identify the residence of whoever bought the bonds in the primary market and track what happens in the secondary market by running periodical surveys. However, very few developing countries are attempting (or have the capability) to identify the ultimate holders of their bonds. Even those that try to do so cannot penetrate the ownership veil for bonds held in offshore financial centers. As a consequence, most countries end up reporting figures for external and domestic debt by using information on the place of issuance and the jurisdiction that regulates the debt contract. This is not a problem, per se. The problem is that the information is misleading because it does not measure what it promises to do (i.e., the transfer of 
resources from non-residents to residents). ${ }^{3}$ This discussion would be irrelevant if there were a close match between place of issuance and residency of the ultimate holder, as used to be the case in the past. However, there is anecdotal evidence that more and more international investors are entering the domestic markets of developing countries and that domestic investors often hold bonds issued in the international market. For instance, a large share of domestic long-term debt issued by the Mexican government is held by US investors and, at the time of the Argentinean debt default, a significant share of Argentinean "external” bonds were held by residents. As a consequence, I tend to prefer the third definition which classifies as external all debt issued under foreign law (this is the definition used in Cowan, Levy Yeyati, Panizza, and Sturzenegger, 2006). While I am aware that the second definition is the one which is theoretically correct, a definition based on jurisdiction is feasible and does not give misleading information on who are the supposed holders of a country's debt.

\subsection{New Environment, Old Dichotomies}

In an environment characterized by open capital accounts and by the presence of foreign investors who buy domestically issued debt and domestic investors who buy debt issued in the international market, the old external/domestic debt dichotomy does not make much sense. Legislation, residence and type of holders, currency, and maturity are all characteristics which are associated with the risks of sovereign finance and the ideal dataset should report information for all these characterises of public debt (see Figure 1 for a description of the ideal dataset). Jurisdiction, for instance, is important in case of a debt default. Knowing who holds the debt is important for assessing whether debt flows involve a net of transfer of external resources across countries and help assess whether holders are likely to be subject to panic attack and lead to runs on a country's public debt. ${ }^{4}$ The currency of denomination is important for determining the risk of currency mismatches, and maturity is important for determining rollover and interest rate risk. Yet, excessive focus on the external/domestic breakdown led to a situation in which the maturity and currency composition of domestically issued debt is not usually included among the vulnerability indicators used to predict financial crises.

\footnotetext{
${ }^{3}$ IMF (2006, 2007) reports that while debt sustainability analysis exercises claim to use an external debt definition based on the residency of the ultimate holder, for the majority of countries there is no information on the residency of the ultimate holders and hence external debt is set to be equal to debt issued in the international market.

${ }^{4}$ Admittedly, domestic as well as foreign bond holders may move assets abroad in a panic.
} 
Figure 1. I deal Debt Classification

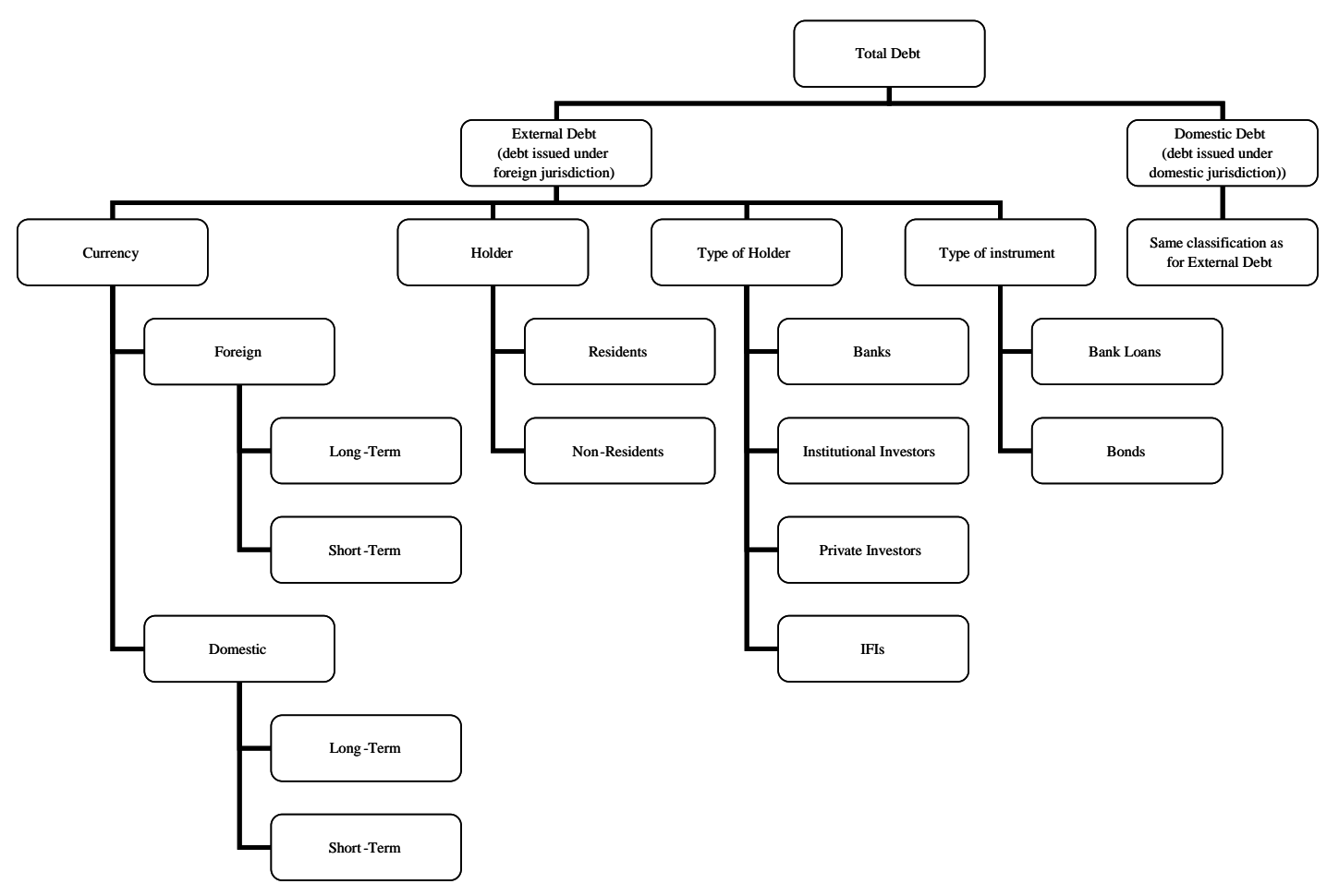

Hence, countries that can provide information on who the holders are should do so and should also publish information on debt composition and structure. However, as some of these data are difficult to obtain, it would be better to start from what we can measure and then work towards the ideal dataset. Only by having a clear idea on what countries can and cannot report we will be able to work towards having accurate and comparable information on the structure of public debt.

\subsection{What do the data say?}

Domestic public debt is not a new phenomenon for developing countries. ${ }^{5}$ Guidotti and Kumar (1991) studied the case of 15 emerging market countries and showed that their ratios of domestic public debt to gross domestic product (GDP) went from 10 percent in 1981 to 16 percent in 1988. Their analysis suggested that if emerging market countries had not been shut out of the international capital market, they would have probably accumulated more external and less domestic debt. Christensen (2005) shows that also low income countries have a tradition of domestic borrowing (in his sample of Sub-Saharan African countries, domestic public debt was about 10 percent of GDP in 1980). As in the case of emerging market countries, also in low income countries external factors are among the main drivers of the accumulation of domestic

\footnotetext{
${ }^{5}$ Since the data in the cited studies and in Table 1 below come from publicly available sources, the external debt data used is based on a mix of the residency and jurisdiction concepts. Thus, it is subject to all the caveats discussed above.
} 
public debt which, somewhat paradoxically, can be driven by either too little foreign aid or too much foreign aid. ${ }^{6}$ Countries that run a budget deficit which is not fully matched by donor flows often issue domestic debt because the standard policy advice of the international financial institutions is to limit external borrowing at commercial rates (for countries that have an IMF program, there are explicit limits on external borrowing at commercial rates).

Build ups of domestic debt driven by excessive foreign aid are also possible and frequent. In order to understand how this can happen, it is useful to classify what a country can do with aid flows. It can: (i) Absorb and spend the aid flows; (ii) Not absorb and not spend the aid flows; (iii) Absorb but not spend; (iv) Spend and not absorb (Aiyar, Berg, and Hussain, 2005). In the fourth case, the government widens its budget deficit but does not use the external aid flows that remain locked in the central banks in the form of international reserves. This is equivalent to a fiscal expansion in the absence of aid and may be driven by the government's decision to sterilize aid inflows. A government that decides to spend and not absorb can either print money or issue domestic debt. It is in this sense that aid can translate into an increase of domestic debt. While this latter policy may look like an odd choice, case studies show that this is not an infrequent strategy among countries that are attempting to avoid an appreciation of the real exchange rate (Aiyar, Berg, and Hussain, 2005).

The above discussion suggests that in the past developing countries used the domestic debt market only when they did not have access to external resources (or to sterilize aid flows). What is new in the current situation is that the increase in domestic financing (both in relative and absolute terms) is happening in a period during which most emerging market countries do have access to the international capital market. The top panel of Table 1 shows that over the 1994-2004 period, domestic public debt went from 17 to 22 percent of developing countries GDP. This happened while average debt levels were decreasing (going from 69 to 65 percent of developing countries' GDP). As a consequence, the share of domestic debt in total public debt went from 23 to 36 percent. The bottom panel of Table 1, reports weighted averages and shows that the switch to domestic borrowing is even more important in larger countries. In this case, the domestic debt-to-GDP ratio went from 16 to 24 percent, and the share of domestic debt in total debt went from 39 to 57 percent. While more recent cross country data are difficult to obtain, anecdotal evidence suggests that this trend accelerated over 2004-2006. In Mexico, for instance, the share of domestic debt went from 61 percent of total public debt in 2004 to 78 percent of public debt in 2006. Brazil was even more aggressive in retiring external debt, and by 2006 the Brazilian public sector had replaced its net external debt with net external assets equal to approximately 3 percent of GDP.

\footnotetext{
${ }^{6}$ Of course, debt relief is a key determinant of the composition of public debt and beneficiaries of debt relief will observe a sudden jump in their share of domestic debt over total debt.
} 
Table 1. Public Debt Composition in Developing Countries

\begin{tabular}{|c|c|c|c|c|c|c|c|c|c|c|c|c|}
\hline & \multicolumn{4}{|c|}{1994} & \multicolumn{4}{|c|}{1999} & \multicolumn{4}{|c|}{2004} \\
\hline & $\mathrm{DD} / \mathrm{Y}$ & $E D / Y$ & $\mathrm{TD} / \mathrm{Y}$ & $\mathrm{DD} / \mathrm{TD}$ & $\mathrm{DD} / \mathrm{Y}$ & $\mathrm{ED} / \mathrm{Y}$ & $\mathrm{TD} / \mathrm{Y}$ & $\mathrm{DD} / \mathrm{TD}$ & $\mathrm{DD} / \mathrm{Y}$ & $E D / Y$ & $\mathrm{TD} / \mathrm{Y}$ & $\mathrm{DD} / \mathrm{TD}$ \\
\hline \multicolumn{13}{|c|}{ Simple Average } \\
\hline EAP & 0.10 & 0.25 & 0.35 & 0.19 & 0.14 & 0.35 & 0.49 & 0.29 & 0.22 & 0.25 & 0.47 & 0.52 \\
\hline ECA & 0.22 & 0.27 & 0.49 & 0.30 & 0.10 & 0.28 & 0.38 & 0.24 & 0.19 & 0.16 & 0.35 & 0.52 \\
\hline LAC & 0.11 & 0.50 & 0.60 & 0.20 & 0.15 & 0.39 & 0.55 & 0.28 & 0.19 & 0.41 & 0.60 & 0.32 \\
\hline MNA & 0.35 & 0.57 & 0.91 & 0.36 & 0.33 & 0.46 & 0.80 & 0.38 & 0.34 & 0.42 & 0.76 & 0.43 \\
\hline SAS & 0.19 & 0.44 & 0.63 & 0.27 & 0.21 & 0.40 & 0.61 & 0.30 & 0.27 & 0.40 & 0.67 & 0.36 \\
\hline SSA & 0.17 & 0.81 & 0.98 & 0.17 & 0.26 & 0.85 & 1.11 & 0.24 & 0.18 & 0.70 & 0.88 & 0.25 \\
\hline Total & 0.17 & 0.52 & 0.69 & 0.23 & 0.20 & 0.49 & 0.69 & 0.28 & 0.22 & 0.43 & 0.65 & 0.36 \\
\hline \multicolumn{13}{|c|}{ Weighted Average } \\
\hline EAP & 0.03 & 0.17 & 0.20 & 0.14 & 0.12 & 0.19 & 0.31 & 0.39 & 0.20 & 0.11 & 0.31 & 0.64 \\
\hline ECA & 0.25 & 0.29 & 0.54 & 0.46 & 0.13 & 0.37 & 0.49 & 0.26 & 0.15 & 0.19 & 0.34 & 0.44 \\
\hline LAC & 0.13 & 0.22 & 0.35 & 0.37 & 0.15 & 0.24 & 0.39 & 0.39 & 0.22 & 0.24 & 0.45 & 0.48 \\
\hline MNA & 0.48 & 0.60 & 1.08 & 0.44 & 0.36 & 0.42 & 0.78 & 0.46 & 0.34 & 0.35 & 0.69 & 0.49 \\
\hline SAS & 0.24 & 0.33 & 0.58 & 0.42 & 0.33 & 0.25 & 0.58 & 0.57 & 0.48 & 0.18 & 0.66 & 0.73 \\
\hline SSA & 0.27 & 0.32 & 0.59 & 0.46 & 0.40 & 0.31 & 0.71 & 0.56 & 0.30 & 0.24 & 0.54 & 0.56 \\
\hline Total & 0.16 & 0.25 & 0.41 & 0.39 & 0.18 & 0.26 & 0.44 & 0.41 & 0.24 & 0.18 & 0.42 & 0.57 \\
\hline
\end{tabular}

Source: Author estimations (see Panizza, 2007, for details)

The regions are defined as follows: EAP: East Asia and Pacific (CHINA, KOREA, INDONESIA, MALAYSIA, PAPUA NEW GUINEA, PHILIPPINES, THAILAND). ECA: East Europe and Central Asia (BELARUS, CZECH REPUBLIC, HUNGARY, POLAND, SLOVAKIA, RUSSIA, TURKEY). LAC: Latin America and the Caribbean (ARGENTINA, BARBADOS, BOLIVIA, BRAZIL, CHILE, COLOMBIA, COSTA RICA, ECUADOR, EL SALVADOR, HONDURAS, GUATEMALA, JAMAICA, MEXICO, NICARAGUA, PANAMA, PARAGUAY, PERU, ST. VINCENT \& GRENADINES, TRINIDAD AND TOBAGO, URUGUAY, VENEZUELA). MNA: Middle East and North Africa (ALGERIA, EGYPT, JORDAN, LEBANON, MOROCCO, OMAN, TUNISIA). SAS: South Asia (BANGLADESH, BHUTAN, INDIA, MALDIVES, NEPAL, PAKISTAN, SRI LANKA). SSA: Sub-Saharan Africa (BURUNDI, CAPE VERDE, ETHIOPIA, GABON, GHANA, GUINEA, MAURITANIA, MAURITIUS, NIGERIA, SIERRA LEONE, SOUTH AFRICA, SUDAN, SWAZILAND, SUDAN, UGANDA).

The debt indicators are domestic debt (DD), external debt (ED) and total debt (TD) as ratios to GDP $(\mathrm{Y})$ and the share of domestic debt in total debt (DD/TD).

The top panel shows the average ratios for the countries in each region. The bottom panel shows the regional averages (i.e., with each country's ratio weighted by its share of regional GDP).

Figure 2 plots the evolution of public debt in 6 developing regions over the 1999-2004 period. In East Asia, the debt to GDP ratio remained constant at approximately 30 percent of GDP, but the share of domestic debt went from 39 to 64 percent of total debt. In the East Europe and Central Asia, Middle East and North Africa, and SubSaharan Africa regions, the debt to GDP ratio decreased substantially. In the first two cases the drop in the debt to GDP ratio was mainly due to a decrease in external debt with a roughly constant share of domestic debt. As a consequence, the share of domestic debt over total debt increased in both regions (going from 26 to 44 percent in ECA and from 46 to 49 percent in MNA). In Sub-Saharan Africa external and domestic debt decreased at the same rate and the share of domestic debt remained constant at approximately 56 percent of total debt. Finally, Latin America and the Caribbean and South Asia exhibited increases in their debt to GDP ratios which are completely explained by increases in domestic borrowing. In the LAC region the 
share of domestic debt went from 39 to 48 percent of total debt and in South Asia, the share of domestic debt went from 57 to 73 percent of total debt.

Figure 2. Composition of Debt-to-GDP ratio (weighted average)

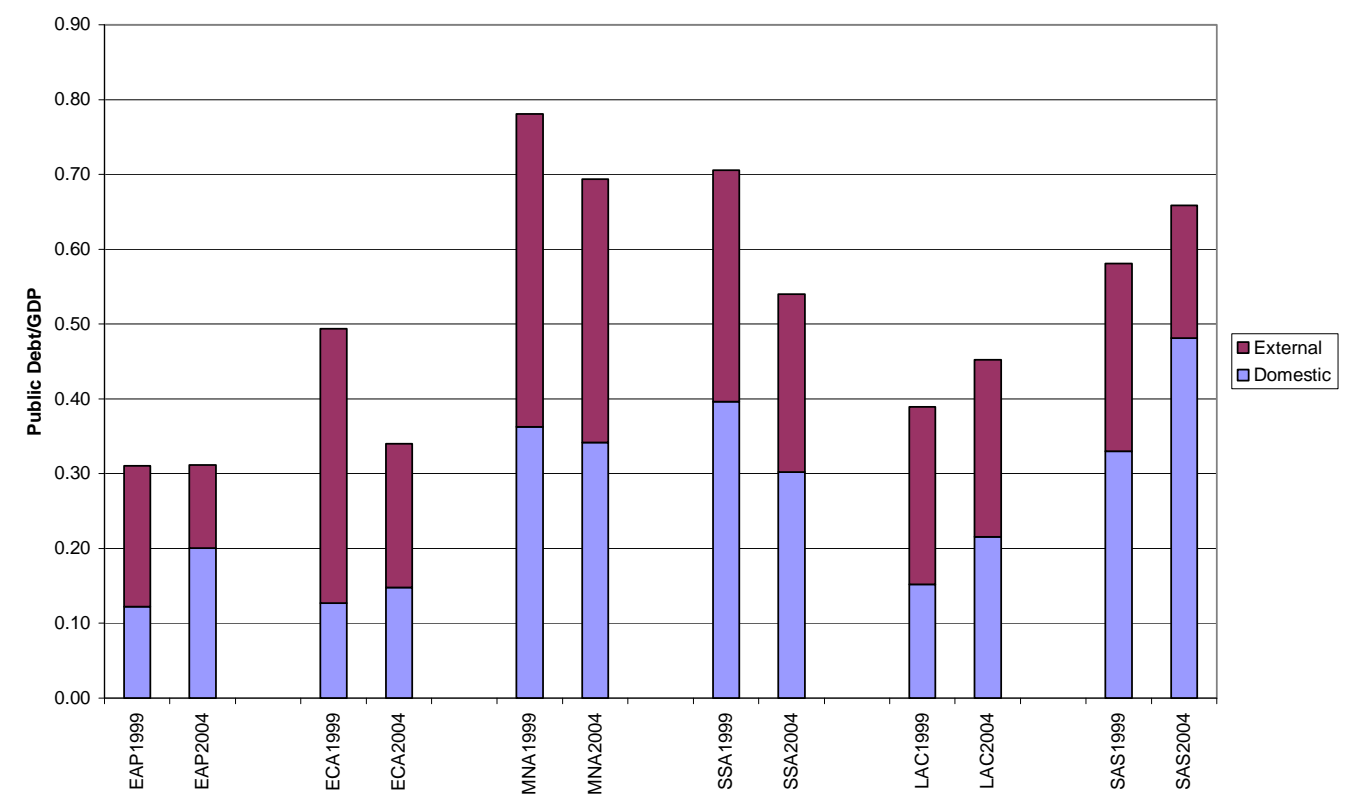

Source: Author's estimations. See footnote to Table 1 for a definition of the regions and a list of countries included in each region. 


\section{CHALLENGES AND OPPORTUNITIES}

The trends documented in the previous section are explained by the fact that the devastating financial crises that hit several emerging market countries in the second half of the 1990s made policymakers well aware of the risks of external borrowing. There is now widespread belief that issuing in the domestic market reduces the risks of sovereign finance. Domestically issued debt has often the advantage of being denominated in the domestic currency and hence may count on a more stable investor base and may reduce currency mismatches (but note, what matters is the currency in which the debt is denominated and not whether the debt is domestic or external). As a consequence, policymakers who are trying to reduce the risk of sovereign finance by limiting excessive foreign borrowing and by developing the required infrastructure and institutional set up for a well performing domestic debt market should be applauded and encouraged. However, the switch to domestic borrowing could entail important trade-offs.

\subsection{Cost}

In low income countries external debt tends to have concessional rates and longmaturity. Hence, even if external borrowing carries a potential currency mismatch, it tends to be cheaper (both ex-ante and ex-post) than domestic borrowing (see Abbas, 2005 for a dissenting view). ${ }^{7}$ For instance, in the sample of 65 low income countries studied by IMF (2006) domestic debt is approximately 21 percent of total debt but it absorbs 42 percent of the total interest bill. ${ }^{8}$ Given its long-term nature concessional external debt is also likely to be safer than domestic debt which often has short maturity and is subject to rollover risk. In fact, UNCTAD (2002) suggests that in Africa increasing reliance on domestically issued bonded debt had a negative effect on both interests cost and financial stability (see Khan, 2005 for a dissenting view).

In emerging market countries, trade-offs are more complicated to evaluate. One first question relates to whether there is a difference between issuing a bond in the international market and issuing a similar bond in the domestic market. Borensztein, Levy Yeyati and Panizza (2006) study the cases of Argentina, Brazil and Colombia and find that bonds issued in the international market tend to be cheaper than similar bonds issued on the domestic market. While one would be tempted to claim that countries could reduce their funding cost without altering their risk profile by issuing more bonds in the international market, it is not clear whether this is a feasible strategy. Some countries may not be able to issue domestic currency denominated bonds in the international market (this is the "original sin" problem, Eichengreen and

\footnotetext{
${ }^{7}$ Of course, this does not mean that the practices of the main providers of concessional debt could not be improved and risk further reduced. For a proposal in this direction see Hausmann and Rigobon (2003).

${ }^{8}$ There is, however, a large variance and in some countries real rates on domestic debt are negative.
} 
Hausmann, 1999) and, even those countries that are able to issue some domestic currency denominated bonds in the international market may not be able to issue a large amount of these bonds. Moreover, if the market does expand, the difference in cost may disappear once these bonds lose their "exotic" status. ${ }^{9}$

A second question relates to comparing issuance of different types of bonds in the same jurisdiction, whether the international market or at home. Even if there is a currency-maturity trade-off, countries may be able to issue long-dated domestic currency debt as long as they are willing to pay the price that the market requires for such bonds. The problem is that this price may not correctly reflect inflation or devaluation expectations and hence be "too high" (see Borensztein, Levy Yeyati and Panizza, 2006, for a discussion of why this may happen). Countries may thus be better off issuing cheaper foreign currency debt which may also help in establishing credibility and anchoring inflationary expectations (Calvo, 1988). However, if lack of credibility is the only obstacle to issuing long-dated domestic currency debt, domestic currency inflation indexed debt dominates foreign currency debt in terms of reducing currency mismatches and dominates nominal domestic currency debt in terms of cost.

Countries should not avoid issuing long-term domestic currency debt only because this type of debt is more expensive than other forms of financing. In fact, there are cases in which the insurance and market creation benefits associated with issuing "safer" debt are well worth the price. In theory, policymakers faced with a menu of financing options should evaluate how much they are willing to pay for safer forms of financing and, if the price is right, go ahead and issue debt denominated in domestic currency or other forms of debt with an imbedded insurance component (for instance, GDP indexed debt, see Borensztein and Mauro, 2004). However, politicians may have incentives to underinsure for at least two reasons. First of all, myopic politicians with short-term objectives may be unwilling to pay a premium for an insurance that will benefit their successors. Second, even well-intentioned politicians may find it politically difficult to pay an insurance premium during good times as this may not be considered a "standard practice."

Caballero and Cowan (2006) use the standard practice arguments to explain why some emerging market countries are now issuing domestic currency denominated debt but not using more efficient forms of insurance. In particular, they suggest that domestic currency borrowing is now en vogue because the expected appreciation allows prudent policymakers to hide the implicit insurance premium embedded in domestic currency borrowing.

\subsection{Risk} ${ }^{9}$ Of course, this cost advantage may also increase due to larger market size and higher liquidity. The
point is that we do not know. 
Broadly speaking, long-term domestic currency debt reduces the risk of maturity and currency mismatches and hence tends to be safer (again, from the borrower's point of view) than short-term foreign currency debt. This is important for the choice between external and domestic borrowing because most developing countries are unable to issue domestic currency debt (either short or long-term) in the international market (Eichengreen, Hausmann and Panizza, 2005a). While most emerging market countries do issue domestic currency bonds in their own market, few of them are able to issue long-term domestic debt at a reasonable interest rate; those that cannot, may face a trade-off between maturity and currency mismatch.

It is not clear what types of policies are necessary to escape this potential trade-off. While most analysts agree that a recent history of low inflation and macroeconomic stability is key for a country's ability to issue domestic long dated bonds in its own currency (Hausmann and Panizza, 2003, Mehl and Reynaud, 2005, and Jeanne and Guscina, 2006), there is less agreements on the potential role of other policy variables including the presence of capital controls, the role of domestic institutional investors, and the participation of foreign investors in the domestic market.

While Hausmann and Panizza (2003) suggest that the presence of capital controls is positively associated with a country's ability to issue domestic long dated bonds in its own currency, Mehl and Reynaud (2005) find that this result is not robust to using a larger sample of countries. The behaviour of individual countries also yield mixed signals. The presence of capital controls has been a key factor for India's ability to finance large budget deficits by issuing long dated bonds in domestic currency (in 2006 the average maturity of Indian domestic government bonds was 16.9 years, Gopinath, 2006). However, Mexico recently issued domestic currency bonds with 20year maturity without needing any sort of capital controls. The difference is that the majority of Indian government bonds are bought by domestic investors (mainly banks) and most of Mexico's long dated bonds are bought by foreign investors (Castellanos and Martinez, 2006) who are desperately looking for yield in an environment characterized by low interested rates and vast liquidity. It remains to be seen if international demand for long-dated Mexican bonds will remain when global liquidity becomes less abundant.

Size matters for bond market development (Borensztein, Cowan, Eichengreen, and Panizza, 2007) and policies aimed at expanding market size include broadening the investor base by promoting the growth of institutional investors and encouraging foreign investors' participation in the domestic market. In 2005, pension funds, mutual funds and insurance companies held one third of central government debt in emerging market countries (Borensztein, Levy Yeyati and Panizza, 2006). Thus, it is not surprising that the presence of large institutional investors is positively associated with the development of the domestic bond market (Borensztein, Cowan, 
Eichengreen, and Panizza, 2007). ${ }^{10}$ However, institutional investors could become victims of their own success and be treated as captive investors by financially constrained governments. This suggests that the presence of large institutional investors could be a mixed blessing. Consider, for instance, the case of a government with sound fiscal fundamentals which is subject to liquidity shortages driven by herd behaviour of poorly informed investors with short-term objectives. In this case, the presence of better informed institutional investors with a long-term investment horizon can increase financial stability and help the government survive the confidence crisis. Consider instead a government that is following unsustainable policies. In this case, the presence of institutional investors which are willing (or are forced) to absorb an increasing amount of government debt could amplify the eventual debt crisis.

Domestic banks often hold a large amount of government debt. In the case of India, for instance, more than 50 percent of government bonds are held by local banks (Gopinath, 2007); in HIPC countries domestic banks' holding of government debt average 61 percent of total domestic debt and range between 33 (Bolivia) and 94 (Ethiopia) percent of total domestic public debt (Arnone and Presbitero, 2006). These large bank holdings of public debt alter the effective maturity of government debt because, during banking crises, long-term government debt held by banks becomes de facto overnight debt. ${ }^{11}$

Policies aimed at promoting the entry of foreign investors in the domestic market are even more controversial. Supporters argue that the presence of foreign investors can help in expanding market size and, by increasing the net flows of external resources into the country, limit crowding out. In this sense having a large presence of foreign investors in the domestic market is equivalent to being able to issue domestic currency debt in the international market. However, policies aimed at promoting the presence of foreign investors may result in a loss of policy space. For instance, such policies are often incompatible with the presence of capital controls and with a country's ability to manage its exchange rate. Moreover, policies aimed at attracting foreign investors may result in sudden inflows of "hot money" and thus lead to high capital flow volatility and financial instability. There is also disagreement on what policies should be implemented to promote the participation of foreign investors in the domestic market (Ito and Park, 2004, discuss possible options for East Asia and Eichengreen, Borensztein and Panizza, 2006, compare East Asia with Latin America).

Debt composition has important implications for the cost of defaulting on debt obligations. The sovereign debt literature highlights two channels through which these costs may materialize: reputation and direct sanctions. However, various empirical

\footnotetext{
${ }^{10}$ As several institutional investors (especially pension funds) tend to adopt buy and hold strategies, their presence is positively associated with the size of the bond market but not with the liquidity of the market (Galindo, Micco and Panizza, 2006).

${ }^{11}$ Thanks to Guillermo Calvo for suggesting this point.
} 
studies found that these costs of default tend to be fairly small (Borensztein and Panizza, 2006, provide a survey of this literature). Borensztein, Levy Yeyati and Panizza (2006) argue that the reason why countries do repay their debt may have more to do with the domestic cost of default which, in turn, is positively correlated with the share of debt held by domestic investors. ${ }^{12}$ As a consequence, domestic debt is more difficult to restructure than external debt. Another reason why defaults on debt denominated in domestic currency tend to be rarer is that policymakers have the option of diluting the debt with inflation rather than recourse to outright default. In deciding whether a domestic debt crisis should be dealt with through high inflation or outright defaults, policymakers need to compare the costs of the different policy options. For instance, default is likely to be more costly in countries where the banking sector holds a large share of government bonds. Inflation is likely to be more costly in countries with low credibility and where most public debt is either in foreign currency, or short term, or indexed to the overnight interest rate.

\subsection{Public Debt and the Domestic Financial Sector}

The government is a big player and the presence of a large and liquid market for government bonds can promote the development of the corporate bond market by building the required minimum size, supplying a benchmark yield curve, and providing the necessary trading infrastructure. ${ }^{13}$ However, in the presence of limited demand for bonded instruments, market creation for government bonds can crowd out lending to the private sector, and excessive reliance on domestic government bonds can stunt the market for corporate bonds. Attempts at testing whether market creation dominates crowding out have yielded mixed results. Eichengreen and Leungnaruemitchai (2004) find no significant correlation between the size of the domestic government bond market and the size of the domestic private bond market and argue that the benefits in terms of market creation balance the costs in terms of crowding out. Eichengreen, Borensztein, and Panizza (2006) find that the share of public debt which is financed with domestic bonds has a positive effect on the size of the corporate bond market. They also find that a larger government bond market is correlated with longer maturity and lower spreads of corporate bonds. The papers collected in Borensztein, Cowan, Eichengreen and Panizza (2007) contain various surveys aimed at testing whether institutional investors value the benefits of a larger government bond market and find that investors in all six countries studied in the volume agreed that having a yield curve is necessary for pricing corporate bonds. Moreover, investors in Chile, Colombia, Mexico, and Uruguay felt that a large stock

\footnotetext{
${ }^{12}$ This is true for both the political and financial cost of a default. A default on domestic investors will carry a higher political cost than a default on foreign investors (who cannot vote politicians out of office). Given that banks are the main domestic holders of government debt issued by developing countries, a default on domestically held is likely to be associated with a banking crisis (Kumhof and Tanner, 2005).

${ }^{13}$ External benefits are also created by issuing government debt on the international market. For instance, the Chilean government issued international bonds in order to create a benchmark for Chilean corporations interested in issuing bonds in the international market (Braun and Briones, 2007).
} 
of public debt is beneficial for the development of the corporate bond market, although Brazilian investors did not agree with this statement. Finally, only Uruguayan and Mexican investors reported that there is direct crowding out and that government and corporate bonds compete in the portfolio.

Positive externalities may come from more than market size. For instance, extending the maturity of government debt may have a market creation effect and can help corporations to issue longer dated debt. However, this policy may also increase the government's incentives to dilute its debt and, by increasing inflationary expectations, have a negative effect on the maturity of corporate debt. In the six countries studied by Borensztein, Cowan, Eichengreen and Panizza (2007) there is no clear patterns of spillovers from the maturity composition of public debt to that of private debt, but this is an area that requires more research.

There are also important interactions between domestically issued government debt and the functioning of the banking sector. Also here the effect can go either way. Most analysts suggest that the fact that in emerging market countries banks are the main holders of government bonds is a source of vulnerability and is a signal that government debt crowds out credit to the private sector. ${ }^{14}$ However, Kumhof and Tanner (2005) suggest that, rather than being a symptom of financial repression, these holding of public debt are largely voluntary and improve the working of the financial sector in countries characterized by poor institutional quality and lack of collateral. In some countries a liquid market for government bonds can further foster financial sector development, leading to more competitive setting of interest rates, and improving the effectiveness of monetary policy. However, these effects are unlikely to be observed in countries with small and underdeveloped financial systems (UNCTAD, 2002).

${ }^{14}$ Crowding out usually manifest itself through higher interest rates, but, can also lead to credit rationing (Stiglitz and Weiss, 1981) in environments in which interest rates are not market determined. 


\section{CONCLUSIONS}

This paper suggests that although the recent switch to domestic borrowing has important positive implications for debt management, policymakers should not be complacent. Domestic government debt can also be dangerous. The choice of the "optimal” debt structure involves balancing important trade-offs and, as vulnerabilities are often identified after a financial crisis starts to unravel (Krugman, 2006), policymakers should be aware of possible new vulnerabilities.

Prevention of debt crises thus requires appropriate monitoring which, in turn, calls for detailed and prompt information on sovereign debt structure and a more inclusive definition of the public sector (which should include the liabilities of local governments, public sector enterprises, and an estimation of contingent liabilities). Yet, most policymakers, researchers, and analysts focus on external borrowing, as prompt and detailed information on the level and composition of domestic public debt is often not available to debt managers and analysts.

Donors can play a major role in helping developing countries to improve their capacity to record and manage public debt. A byproduct of better recording of public liabilities would be the ability to disseminate more information on the structure of total public debt. This would help the research community identify possible new vulnerabilities and further improve a country's debt management strategy and thus reduce the risk of a debt crisis. There are, however, important externalities in data collection and dissemination. While better data availability can help in devising better debt management strategies and reduce the probabilities of debt crises, each individual country does not internalize the full benefits of having a global set of data on debt level and composition. This situation leads to an under provision of data collection and dissemination and generates a natural area of intervention for the official sector. The creation of the Debt Management — DMFAS Program of UNCTAD (see http://r0.unctad.org/dmfas/) and the Debt Recording and Management System of the Commonwealth Secretariat (see http://www.csdrms.org/) were important steps in this direction, but more resources, continuous support, and more coordination among these agencies and the various national debt offices are needed.

A last issue has to do with the debt measure that should be used in debt sustainability assessments. The current practice consists of either using external debt or total public debt. Both practices are problematic. The first practice consists of giving weight 1 to all external debt and weight zero to all domestic public debt. The second practice consists of giving weight one to all types of debt (external and domestic). However, different types of debt are associated with different probabilities of a debt crisis and the ideal indicator should assign a higher weight to "riskier" and a lower weight to "safer" forms of debt. Better information on debt structure and more research on 
vulnerabilities arising from different types of debt could help us in building such an indicator and, by doing a better job at tracking the risks of debt crises, improving debt management and reducing the probability of debt crises. 


\section{REFERENCES}

Abbas, A. (2005). 'Public Debt Sustainability and Growth in Sub-Saharan Africa: The Role of Domestic Debt', in GDN Project on the Macroeconomics of Low Income Countries.

Aiyar, S., Berg, A., and Hussain, M. (2005). 'The Macroeconomic Challenge of More Aid'. Finance and Development 42/3.

Arnone, M., and Presbitero, A. (2006). External Debt Sustainability and Domestic Debt in Heavily Indebted Poor Countries. Catholic University Milan and Universitá Politecnica delle Marche, mimeo.

Beaugrand, P., Loko, B., and Mlachila, M. (2002). The Choice between External and Domestic Debt Financing Budged Deficits: The Case of Central and West African Countries. IMF Working Paper 02/79. Washington, D.C.: IMF.

Borensztein, E., Cowan, K., Eichengreen, B., and Panizza, U. (2007). On the Verge of a Big Bang? Bond Markets in Latin America. MIT Press (forthcoming).

, Levy-Yeyati, E., and Panizza, U. (2006). Living with Debt. Inter-American Development Bank Report on Economic and Social Progress in Latin America. Harvard University Press and Inter-American Development Bank. , and Mauro, P. (2004). 'The Case for GDP-Indexed Bonds', Economic Policy 19/38: 165-216.

, and Panizza, U. (2006). 'The Cost of Default'. Inter-American Development Bank, Washington, DC. Unpublished.

Braun, M., and Briones, I. (2007). 'The Development of the Chilean Bond Market' in Borensztein, Cowan, Eichengreen, and Panizza (eds.) On the Verge of a Big Bang? Bond Markets in Latin America. MIT Press (forthcoming).

Broda, C., and Weinstein, D. (2004). Happy News from the Dismal Science: Reassessing the Japanese Fiscal Policy and Sustainability. NBER Working Paper 10988.

Caballero, R., and Cowan, K. (2006). Financial Integration without the Volatility. MIT, mimeo.

Calvo, G. (1988). 'Servicing the Public Debt: The Role of Expectations'. American Economic Review 78/4: 647-61.

(2005). Emerging Capital Markets in Turmoil. MIT Press.

Campos, C., Jaimovich, D., and Panizza, U. (2006). 'The Unexplained Part of Public Debt’. Emerging Markets Review, 7: 228-243. 
Castellanos, S., and Martínez, L. (2006). 'The Development and Challenges Faced by the Mexican Bond Market', in Borensztein, Cowan, Eichengreen, and Panizza (eds) On the Verge of a Big Bang? Bond Markets in Latin America. MIT Press (forthcoming).

Cowan, K., Levy-Yeyati, E., Panizza, U., and Sturzenegger, F. 'CLYPS. Sovereign Debt in The Americas: New Data and Stylized Facts'. Inter-American Development Bank, Research Department Working Paper 577.

Christensen, J. (2006). Special Data Section Domestic Debt Markets in Sub-Saharan Africa. IMF Staff Papers 52/3: 518-538.

de Bolle, M., Rother, B., and Hakobyan, I. (2006). The Level and Composition of Public Sector Debt in Emerging Market Crisis. IMF Working paper 06/186.

Dohdia, D. (2007). 'Domestic Debt Architecture in the Context of the Millennium Development Goals’. Unpublished.

Eichengreen, B., Borensztein, E., and Panizza, U. (2006). ‘A Tale of Two Markets: Bond Market Development in East Asia and Latin America' (with E. Borensztein and B. Eichengreen) Hong Kong Institute for Monetary Research Occasional Paper no. 3.

, and Hausmann, R. (1999). 'Exchange Rates and Financial Fragility'. Paper presented at the symposium New Challenges for Monetary Policy, August 2628, Jackson Hole, WY.

, Hausmann, R., and Panizza, U. (2005a). 'The Pain of Original Sin' in B. Eichengreen and R. Hausmann (eds.) Other People's Money. Chicago: Chicago University Press.

, Hausmann, R., and Panizza, U. (2005b). ‘The Mystery of Original Sin’ in B. Eichengreen and R. Hausmann (eds.) Other People's Money. Chicago: Chicago University Press. , and Luengnaruemitchai, P. (2004). Why Doesn't Asia Have Bigger Bond Markets? NBER Working Paper no. 10576. National Bureau of Economic Research, Cambridge, MA.

Galindo, A., Micco, A., and Panizza. U. (2006). 'Two Decades of Financial Reforms' in E. Lora (ed.) The State of State reform in Latin America. Stanford: Stanford University Press.

Gopinath, S. (2007). Development of Local Currency Bond Markets - The Indian Experience. Federal Reserve Bank of India, mimeo.

Guidotti, P., and Kumar, M. (1991). Domestic Public Debt of Externally Indebted Countries. IMF Occasional Paper N. 80. 
Hausmann, R., and Panizza, U. (2003). 'On the Determinants of Original Sin: An Empirical Investigation'. Journal of International Money and Finance 22/7: 957-90.

, Panizza, U., and Rigobon, R. (2006). 'The Long-Run Volatility Puzzle of the Real Exchange Rate’ Journal of International Money and Finance. 25: 93124.

, and Rigobón, R. (2003). IDA in UF: On the Benefits of Changing the Currency Denomination of Concessional Lending to Low-Income Countries. Harvard University, Cambridge, MA. Unpublished.

International Monetary Fund. (2003). Sustainability Assessment- Review of Application and Methodological Refinements. IMF, mimeo.

(2006). Applying the Debt Sustainability Framework for Low Income Countries Post Debt Relief. IMF, mimeo.

(2007). Staff Guidance Note on the Application of the Joint Fund-Bank Debt Sustainability Framework for Low Income Countries. IMF, mimeo.

and World Bank. (2004). Debt Sustainability in Low-Income Countries-Proposal for an Operational Framework and Policy Implications. IMF, mimeo.

Ito, T., and Park, Y. C. (2004). Developing Asian Bond Markets: Challenges and Strategies. Australian National University Asia Pacific Press.

Jaimovich, D., and Panizza, U. (2006). 'Public Debt around the World'. InterAmerican Development Bank, Research Department Working Paper \#561.

Jeanne, O., and Guscina, A. (2006). Government Debt in Emerging Market Countries: A New Data Set. IMF Working Paper no. 06/98. International Monetary Fund, Washington, DC.

Kahn, Brian. (2005). "'Oruginbal Sin" and Bond Market Development in SubSaharan Africa' in Teunissen and Akkerman (eds), Africa in the World Economy. FONDAD.

Krugman, P. (2006). Will There Be a Dollar Crisis? Princeton, mimeo.

Kumhof, M., and Tanner, E. (2005). Government Debt: A Key Role in Financial Intermediation. IMF Working paper 05/57.

Mehl, Arnaud, and Julien Reynaud. 2005. The Determinants of "Domestic” Original Sin in Emerging Market Economies. ECB Working Paper no. 560. European Central Bank, Frankfurt am Main, Germany.

Panizza, U. (2007). Domestic Public Debt in Developing Countries. UNCTAD, mimeo. 
Stiglitz, J., and Weiss, A. (1981). 'Credit rationing in Markets with Incomplete Information’. American Economic Review, 71: 393-410.

UNCTAD. (2002). From Adjustment to Poverty Reduction: What is New? Economic Development in Africa. Geneva: UNCTAD. 